\title{
A Novel Selective Melanocortin-4 Receptor Agonist Reduces Food Intake in Rats and Mice without Producing Aversive Consequences
}

\author{
Stephen C. Benoit, ${ }^{1}$ Michael W. Schwartz, ${ }^{2}$ Jennifer L. Lachey, ${ }^{1}$ Mary M. Hagan, ${ }^{1}$ Paul A. Rushing, ${ }^{1}$ \\ Kathleen A. Blake ${ }^{1}$ Keith A. Yagaloff, ${ }^{3}$ Grazyna Kurylko, ${ }^{3}$ Lucia Franco, ${ }^{3}$ Waleed Danhoo, ${ }^{3}$ and \\ Randy J. Seeley ${ }^{1}$ \\ ${ }^{1}$ Department of Psychiatry, University of Cincinnati, Cincinnati, Ohio 45267, 2University of Washington, Department of \\ Veterans Affairs, Puget Sound Health Care System, Seattle, Washington 98108-1597, and '3epartment of Metabolic \\ Diseases, Hoffmann-La Roche Inc., Nutley, New Jersey 07110
}

Studies using nonselective agonists and antagonists of melanocortin-3 receptor (MC3R) and MC4R point to the importance of the CNS melanocortin system in the control of food intake. We describe here a novel compound that is highly selective as an agonist at the MC4 receptor but has minimal activity at the MC3 receptor. When administered centrally to rats, this selective agonist increased Fos-like immunoreactivity in the paraventricular nucleus, central nucleus of the amygdala, nucleus of the solitary tract, and area postrema, a pattern of neuronal activation that is similar to that induced by a nonselective MC3/4R agonist. Additionally, it suppresses food intake when administered centrally to rats or peripherally to $d b / d b$

Recent evidence points to the hypothalamic melanocortin (MC) peptide system as critical in the control of energy balance. Neurons that express mRNA for the MC precursor molecule, proopiomelanocortin (POMC), are found in the arcuate nucleus (ARC) and project to other hypothalamic sites. Evidence suggests that these POMC neurons express leptin receptors and that central MC signaling contributes to the effects of the adipocyte hormone leptin (Cheung et al., 1997; Mountjoy and Wong, 1997; Seeley et al., 1997). Within the brain, two receptor subtypes for melanocortins are expressed, MC3R and MC4R (Mountjoy et al., 1994). Several nonselective ligands of these receptors have been identified and assessed for their effect on food intake (Fan et al., 1997; Grill et al., 1998). $\alpha$-Melanocyte-stimulating hormone ( $\alpha$ MSH), synthesized within ARC POMC neurons, is an agonist of MC3R and MC4R (Adan et al., 1994) that, after exogenous central administration, robustly decreases food intake in rats (Tsujii and Bray, 1989). MTII is a synthetic analog of $\alpha$-MSH that also has agonistic properties at both MC3R and MC4R and decreases food intake and body weight of mice and rats (Fan et al., 1997; Thiele et al., 1998).

Interestingly, MC receptors are one of the few signaling systems for which endogenous antagonists, as well as agonists, have been identified. Agouti is a protein that is normally expressed in the skin and is an antagonist of the cutaneous MC receptor involved in pigmentation, MC1R (Ollmann et al., 1997, 1998).

Received Oct. 25, 1999; revised Feb. 3, 2000; accepted Feb. 17, 2000.

This work was supported by National Institutes of Health Grants DK54890, DK54080, DK17844, and NS32273.

Correspondence should be addressed to Stephen C. Benoit, Department of Psychiatry, University of Cincinnati, College of Medicine, Box 670559, Cincinnati, OH 45267-0559. E-mail: benoits@email.uc.edu.

Copyright (C) 2000 Society for Neuroscience $0270-6474 / 00 / 203442-07 \$ 15.00 / 0$ mice that lack functional leptin receptors via a mechanism that is not accompanied by illness or other nonspecific effects. Conversely, a related compound that is a selective MC4R antagonist potently increased food intake when administered centrally in rats. These results support the hypothesis that the brain MC4R is intimately involved in the control of food intake and body weight and provide evidence that selective activation of MC4R causes anorexia that is not secondary to aversive effects.

Key words: melanocortins; MC4-R; hypothalamus; food intake; taste aversion; c-Fos

Ectopic overexpression of the agouti protein in $\mathrm{A}^{\mathrm{Y}}$ mice therefore results in both yellow coat color because of antagonism of $\mathrm{MC} 1 \mathrm{R}$ and increased food intake and body weight because of abnormal antagonism of MC4R (Lu et al., 1994). Agouti-related protein (AgRP) is homologous to agouti, which is synthesized exclusively in a population of ARC neurons that are distinct from those expressing POMC. AgRP antagonizes both MC3R and MC4R but not MC1R (Fong et al., 1997). Consequently, genetic overexpression of AgRP or exogenous administration of an AgRP fragment increases food intake and causes obesity but does not alter pigmentation (Ollmann et al., 1997; Rossi et al., 1998). Furthermore, central administration of a nonselective MC3/4R antagonist (SHU-9119) increases food intake in normal rats and mice (Fan et al., 1997; Hagan et al., 1999). Collectively, these data suggest that central $\mathrm{MC} 3 / 4$ receptors participate in energy homeostasis.

An important unanswered question is whether the two centrally expressed $\mathrm{MC}$ receptors have different roles in the control of energy balance. We report here the use of two new compounds that have specific affinity for the MC1R and MC4R. Because MC1R has only been found in periaquiductal gray matter of humans (Xia et al., 1995), we expect central administration of these compounds results in selective activation at MC4R. We therefore measured the effects of these compounds on food intake in rats and $d b / d b$ mice, which develop obesity because of autosomal recessive mutation of the long-form leptin receptor. In addition, we report results of behavioral tests for aversive consequences of the selective MC4R agonist.

\section{MATERIALS AND METHODS}

Subjects and materials. All animal procedures were approved by the institutional animal care and use committee of the University of Cincin- 
nati. Male Long-Evans rats were individually housed in stainless steel cages and maintained on a $12 \mathrm{hr}$ light/dark cycle. Laboratory chow (Purina 5001) and water were provided ad libitum (except where noted) during the experiments. Seven days after arrival in the laboratory, rats were anesthetized with $3.3 \mathrm{ml} / \mathrm{kg}$ equithesin and implanted with a 21-gauge stainless steel cannula (Plastics One, Roanoke, VA) aimed at the third ventricle (i3vt) $2.2 \mathrm{~mm}$ posterior to bregma and $7.4 \mathrm{~mm}$ ventral to dura (for review, see Seeley et al., 1996). Placement and patency of cannulas were confirmed by administration of $10 \mathrm{ng}$ of angiotensin II in saline while the animals were water replete. Animals that did not drink at least $5 \mathrm{ml}$ of water within $60 \mathrm{~min}$ were considered to have failed cannula placement and were not used in the experiments. Rats that received taste aversion training were also implanted unilaterally with intraoral cannulas constructed of polyethelene-100 tubing, which allows liquid stimuli to be infused directly into the oral cavity. These were placed anterolateral to the first maxillary molar and were threaded subcutaneously to exit the top of the head (for review, see Thiele et al., 1998).

Obese C57/B6 $d b / d b(n=10)$ mice were purchased from The Jackson Laboratory (Bar Harbor, ME). The mice were individually housed in plastic tubs and maintained on a $12 \mathrm{hr}$ light/dark cycle. They were fed and watered ad libitum, except where noted. Each mouse received one intraperitoneal injection of saline $(0.9 \%, 200 \mu \mathrm{l})$ and one injection of Ro27-3225 (200 $\mu \mathrm{g}, 200 \mu \mathrm{l})$.

For all experiments with rats, i3vt infusions were administered in volumes of $2 \mu \mathrm{l}$. Intraperitoneal injections were all isotonic and delivered in $\mathrm{NaCl}$ vehicle volumes of $20 \mathrm{ml} / \mathrm{kg}$ (rat) or $200 \mu \mathrm{l}$ (mouse). In all experiments on food intake, subjects received manipulations immediately before onset of the dark phase.

Experiment 1: MCR-based assays. All assays were performed in duplicate. Binding assays were performed using membranes prepared from HEK293 cells stably transfected with human MC1R, MC3R, MC4R, and MC5R. Binding of $\left[{ }^{125} \mathrm{I}\right]\left[\mathrm{Nle}^{4} \text {, D-Phe }{ }^{7}\right]^{7}-\mathrm{MSH}$ (NDP-MSH) (labeled via chloramines T method, $2000 \mathrm{Ci} / \mathrm{nmol}$ specific activity) (catalog \#IM316; Amersham Pharmacia Biotech, Arlington Heights, IL) to the membrane homogenates was done as follows: $20 \mathrm{mg}$ of wheat germ agglutinin scintillation proximity assay (SPA) beads (Amersham Pharmacia Biotech) was resuspended with $10 \mathrm{ml}$ of $50 \mathrm{~mm}$ HEPES, $10 \mathrm{mM} \mathrm{MgCl}$, and $0.1 \%$ BSA, $\mathrm{pH}$ 7.4. Concentrated membrane homogenate was added to give a final concentration of $0.04 \mathrm{mg} / \mathrm{ml}$ (MC1R, MC3R, and MC5R) and $0.032 \mathrm{mg} / \mathrm{ml}$ (MC4R). The mixture of SPA beads plus homogenate was incubated for $1 \mathrm{hr}$ at $4^{\circ} \mathrm{C}$ with constant and vigorous mixing. Assays were initiated by distributing $50 \mu \mathrm{l}$ of SPA membrane into 96 well plates (Optiplate polystyrene microplate; Packard, Meridian, CT), and $2 \mu \mathrm{l}$ of compounds at various concentrations or DMSO was added. Nonspecific binding was determined by adding an excess of unlabeled NDP-MSH (2 $\mu \mathrm{M})$. The final concentration of labeled NDP-MSH in the assay was 0.2 (MC1R), 1.0 (MC3R), 0.1 (MC4R), and 0.4 (MC5R) nM. Plates were shaken overnight at room temperature on mini-orbital shaker $(20-24 \mathrm{hr})$. Radioactivity was counted in a $\beta$ scintillation counter for 2 min (Topcount; Packard).

HEK293 transfected with the MC1R, MC3R, MC4R, or MC5R were grown in DMEM containing 10\% FBS and $500 \mu \mathrm{g} / \mathrm{ml} \mathrm{G} 418$ sulfate in 96 well flat-bottom tissue culture-treated plates. Cells were stimulated at confluence (days 2-4) with either $100 \mathrm{nM} \mathrm{NDP}-\alpha \mathrm{MSH}$ or compound. In the agonist assay, compounds Ro27-4680 [molecular weight (MW) of 949.01] and Ro27-3225 (MW of 898.80) (Fig. 1) were serially diluted in $100 \%$ DMSO and were further diluted 1:200 (2.5 $\mu$ l of compound dilution plus $500 \mu$ l of media) in DMEM containing $10 \%$ FBS and $0.1 \mathrm{~mm}$ 3-isobutyl-1-methylxanthine. Data were collected for 10 different concentrations of both compounds ranging from 50 to $0.02 \mathrm{nM}$. For NDP$\alpha \mathrm{MSH}$-stimulated cells, $2.5 \mu \mathrm{l}$ of $20 \mu \mathrm{M}$ NDP- $\alpha \mathrm{MSH}$ in $100 \% \mathrm{DMSO}$ was added to $500 \mu \mathrm{l}$ of media (final concentration $100 \mathrm{~nm}$ ). For unstimulated cells, $2.5 \mu \mathrm{l}$ of DMSO was added to $500 \mu \mathrm{l}$ of media. To determine antagonist effect of Ro27-4680 on MC3R and MC4R, cells were incubated in the presence of a fixed concentration of NDP- $\alpha$ MSH (20 nM MC3R and MC4R) or Ro27-3225 (250 nM MC4R or $2000 \mathrm{~nm}$ MC3R).

Culture medium was removed from confluent 96 well culture plates and replaced with $200 \mu \mathrm{l}$ of above dilutions into the appropriate wells. The plates were incubated for $1 \mathrm{hr}$ at room temperature. At the end of incubation, plates were washed one time with $200 \mu \mathrm{l} /$ well PBS. cAMP was extracted by the addition of $60 \mu \mathrm{l}$ of $70 \%$ ethanol (room temperature). After a $30 \mathrm{~min}$ extraction period, plates were stored at $-20^{\circ} \mathrm{C}$ until the cAMP assay was performed.

Forty (MC1R and MC4R) or 20 (MC3R and MC5R) $\mu$ l of assay buffer,
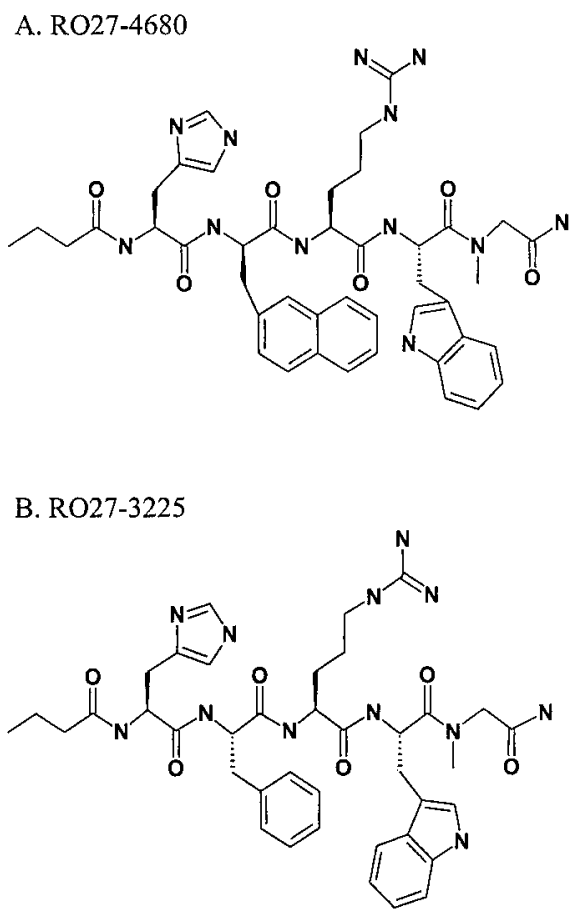

Figure 1. Two-dimensional structure of the selective MC4R agonist (Ro27-3225) and the selective antagonist (Ro27-4680).

10 (MC1R and MC4R) or 30 (MC3R and MC5R) $\mu$ l of ethanol extract, $50 \mu \mathrm{l}$ of $\left[{ }^{125} \mathrm{I}\right] \mathrm{cAMP}, 50 \mu \mathrm{l}$ of antiserum, and $50 \mu \mathrm{l}$ of SPA beads were added to a 96 well plate. The total well volume after addition was $200 \mu \mathrm{l}$. The plates were sealed and incubated for $15-20 \mathrm{hr}$ at room temperature. $\left[{ }^{125} \mathrm{I}\right] \mathrm{cAMP}$ binding to the SPA beads was determined by counting for 2 min. Each plate contained controls for unstimulated cells and NDP$\alpha \mathrm{MSH}$ for stimulated cells.

Experiment 2: food intake in rats. After recovery from i3vt cannulation, food intake was measured for at least $3 \mathrm{~d}$ to establish baseline. On test days, rats were weighed and food hoppers were removed from cages $2 \mathrm{hr}$ before the beginning of the dark phase. Rats $(n=8$ per group) then received i3vt infusion of $0.0,0.1,1.0,3.0,5.0$, or $10.0 \mathrm{nmol}$ of either the MC4R antagonist (Ro27-4680) or MC4R agonist (Ro27-3225) in saline immediately before the onset of the dark phase. Inf usions were delivered in a volume of $2 \mu \mathrm{l}$ over $60 \mathrm{sec}$. Food intake was recorded at 1,2,3, and $4 \mathrm{hr}$ after infusion.

Experiment 3: food intake in $\mathrm{db} / \mathrm{db}$ mice. On the day before the first injections, mice in each group (wild type, $n=10 ; d b / d b, n=10$ ) were divided into two subgroups matched for body weight and daily food intake. On test days, food hoppers were removed from the home cages 2 $\mathrm{hr}$ before the beginning of the dark phase. At the time of lights out, the mice received intraperitoneal injections of either saline or $200 \mu \mathrm{g}$ of Ro27-3225, and food was returned. Food intake was measured after 1 and $4 \mathrm{hr}$. Two days after the first injection, the mice received the alternate injections, and the same protocol was followed.

Experiment 4: conditioned taste aversion. Rats $(n=32)$ were first habituated to a Plexiglas observation chamber and intraoral infusion of fluid for $20 \mathrm{~min} / \mathrm{d}$ over $4 \mathrm{~d}$. During the last two habituation sessions, rats were intraorally infused with $5 \mathrm{ml}$ of distilled water $(0.5 \mathrm{ml} / \mathrm{min})$ during the first $10 \mathrm{~min}$ in the conditioned taste aversion (CTA) chamber. On the day after habituation, one-half of the rats received either i3vt CSF or intraperitoneal $\mathrm{NaCl}$ (paired group); the remaining rats were given i3vt Ro27-3225 or intraperitoneal $\mathrm{LiCl}$ (unpaired group). All rats were then immediately returned to the home cage. On the conditioning day, rats were placed in the observation chambers and infused intraorally with $1.0 \%$ saccharin $(2.5 \mathrm{ml}$ over $5 \mathrm{~min})$. Immediately after the inf usions, rats in the paired group received either i3vt infusion of $5 \mathrm{nmol}$ of Ro-273225 or intraperitoneal $\mathrm{LiCl}$; rats in the unpaired group received either i3vt $\mathrm{CSF}$ or intraperitoneal $\mathrm{NaCl}$. On the test day, rats were returned to the observation chambers and again intraorally infused with the $1.0 \%$ saccharine solution $(2.5 \mathrm{ml}$ over $5 \mathrm{~min})$. The amount of time that passed before rats rejected (passive or active expulsion) the fluid was recorded. 
Table 1. Affinity and agonist activity

Agonist assay
Antagonist assay

\begin{tabular}{ll}
\hline Ro27-4680 & \\
\hline w/NDP- $\alpha$ MSH & w/ Ro27-3225 \\
$(20 \mathrm{nM})$ & $(250 \mathrm{nM})$ \\
$\mathrm{IC}_{50}(\mathrm{~nm})$ & $\mathrm{IC}_{50}(\mathrm{~nm})$ \\
\hline No activity & No activity \\
$4989(472.7)$ & $7329(1433.3)^{a}$ \\
$13890(3808)^{b}$ & $4153(479.8)^{c}$ \\
No activity & No activity
\end{tabular}

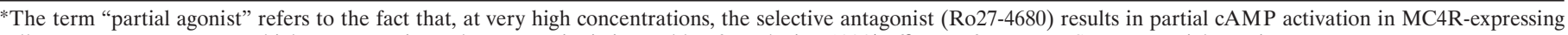
cells. However, even at very high concentrations, the antagonist is incapable of producing $100 \%$ efficacy of NDP- $\alpha$ MSH. pa, Partial agonist.

${ }^{a}$ Ro27-3225 concentration of $2.0 \mu \mathrm{M}$.

${ }^{b}$ Partial antagonist of NDP- $\alpha \mathrm{MSH}$.

${ }^{c}$ Partial antagonist of Ro27-3225.

We have previously used this paradigm to assess the aversive consequences of i3vt infusion of MTII (Thiele et al., 1998).

Experiment 5: $\mathrm{NaCl}$ intake. Rats $(n=32)$ were first habituated to 0.5 $\mathrm{M} \mathrm{NaCl}$ bottles for $7 \mathrm{~d}$ and then sodium deprived for $1 \mathrm{~d}$. On the sodium deprivation day, rats were injected subcutaneously with furosemide (2 $\mathrm{ml} / \mathrm{kg}$ ), and clean food hoppers containing sodium-free rat chow were placed in the home cages. Twenty-four hours later, rats received one i3vt inf usion (Ro27-3225 or CSF), followed 15 min later by a single intraperitoneal injection $(\mathrm{LiCl}$ or $\mathrm{NaCl})$. There were four combinations of these treatments ( $n=8$ per group). The first group received CSF followed by saline. The second group received $3 \mathrm{nmol}$ of Ro27-3225 followed by saline. The third group received $5 \mathrm{nmol}$ of Ro27-3225 followed by saline. The final group of rats received CSF followed by intraperitoneal LiCl. Intake of the $0.5 \mathrm{M} \mathrm{NaCl}$ solution was measured after $2 \mathrm{hr}$.

Experiment 6: kaolin intake. Rats $(n=32)$ were first habituated to kaolin clay pellets in the home cage ( $200 \mathrm{gm}$ in a second food hopper). On the test day, rats received one i3vt infusion of CSF or Ro27-3225, followed by a single intraperitoneal injection of saline or LiCl. Paper was placed beneath the home cages to collect spillage. Kaolin clay intake was then measured $2 \mathrm{hr}$ after infusion. Drug groups ( $n=8$ per group) and order of injections were identical to those of experiment 4.

Experiment 7: $5 \mathrm{nmol}$ of Ro27-3225. After completion of the aversiveness assays, the time course of $5.0 \mathrm{nmol}$ of Ro27-3225 to reduce food intake was again assessed, in a within-subjects comparison. On test days, rats were weighed and food hoppers were removed from cages $2 \mathrm{hr}$ before the beginning of the dark phase. Ten rats then received i3vt infusion of 0.0 or $5.0 \mathrm{nmol}$ of the MC4 agonist (Ro27-3225) immediately before the onset of the dark phase. On the second test day, rats received the alternate infusion (i.e., $0.0 \mathrm{nmol}$, followed by 5.0 and $5.0 \mathrm{nmol}$, followed by $0.0 \mathrm{nmol}$ ). Food intake was recorded at $1,2,3$, and $4 \mathrm{hr}$ after inf usion on both test days.

Experiment 8: c-Fos immunohistochemistry. Twelve rats, used previously for an experiment that required i3vt cannulas, were infused with artificial CSF (a-CSF), $1.0 \mathrm{nmol}$ of MTII, or $5.0 \mathrm{nmol}$ of Ro27-3225 ( $n=$ 4 per treatment). Two hours after the infusions, rats were intracardially perfused with $0.9 \%$ PBS, followed by $4.0 \%$ paraformaldehye in $0.1 \mathrm{M}$ phosphate buffer. Brains were removed and post-fixed $\sim 4 \mathrm{hr}$. They were then stored in $30 \%$ sucrose PBS for $\sim 3$ weeks. Brains were then snap frozen and sectioned at $50 \mu \mathrm{m}$. Forebrain slices were cut in the coronal plane to allow visualization of the paraventricular nucleus of the hypothalamus (PVN) and central nucleus of the amygdala (CeA). Sections through the hindbrain were made in the horizontal plane to facilitate visualization of the nucleus of the solitary tract (NTS). Sections were rinsed (three times, PBS), incubated for $20 \mathrm{~min}$ in $0.3 \% \mathrm{H}_{2} \mathrm{O}_{2}$ to quench endogenous peroxidase, rinsed (three times, PBS), and incubated $1 \mathrm{hr}$ in $0.1 \%$ normal donkey serum in PBS and $0.2 \%$ Triton X-100. Sections were then transferred to the primary antibody solution consisting of 0.005 $\mathrm{gm} / \mathrm{ml}$ polyclonal rabbit antiserum (Santa Cruz Biotechnology, Santa Cruz, CA) which recognizes residues 3-16 of the c-Fos protein. After $\sim 24 \mathrm{hr}$ incubation, slices were rinsed (four times, PBS) and processed with the ABC method (Vector Laboratories, Burlingame, CA). Slices were transferred to biotinylated donkey anti-rabbit antibody for $1 \mathrm{hr}$, rinsed (four times, PBS) and then transferred to avidin-biotinylated peroxidase for $1 \mathrm{hr}$, rinsed (four times, PBS), and developed with diaminobenzidine substrate (10 min). Slices were then rinsed (four times, PBS), mounted on slides, and coverslipped with Permount. c-Fos like immunoreactivity (c-FLI) was detected with a video camera installed on the microscope using OptiQuant image processing software. Sections examined for c-FLI included the PVN, area postrema (AP), NTS, and CeA.

\section{RESULTS}

For designs incorporating single-factor between-subjects designs (e.g., experiment 2), data were analyzed with one-way ANOVA across drug treatment (e.g., saline-CSF, Ro27-3225, and LiCl). For designs using single-factor within-subjects designs, one-way repeated measures ANOVA was conducted across drugs. For experiment 4, a two-way ANOVA was conducted using drug and learning treatment as factors. Post hoc analyses used either LSD or Tukey's HSD test with significance set at $p<0.05$.

\section{Experiment 1: MCR-based assays}

Table 1 shows affinity and agonist activity of the selective agonist (Ro27-3225) and the selective antagonist (Ro27-4680). Both compounds showed significantly lower $\mathrm{IC}_{50}$ values for cells transfected with the MC4R over the MC3R. Ro27-3225 also showed a lower $\mathrm{EC}_{50}$ in cells transfected with the MC4R compared with MC3R, whereas Ro27-4680 showed no induced agonist activity in cells transfected with either the MC3R or MC4R. Hence, as measured by either binding or activation of cAMP, Ro27-3225 shows $\sim 30$-fold selectivity for MC4R over MC3R.

The binding and cAMP assays did, indeed, yield different estimations of the selectivity of 3225 . It should be noted that the MC4R may contain multiple binding sites. These multiple binding sites may or may not exert independent changes in resulting cAMP. If this were the case, one might expect to observe higher estimations of binding than of cAMP activation.

\section{Experiment 2: food intake in rats}

Ro27-4680 produced an increase of short-term food intake at the beginning of the dark cycle, with the maximal response detected at doses of $5 \mathrm{nmol}$ (Fig. 2, top panel ). Results of ANOVA and post $h o c$ tests support these conclusions. Food intake was increased twofold $(p<0.05)$ relative to saline at the $5 \mathrm{nmol}$ dose. In contrast, Ro27-3225 dose-dependently decreased food intake over the first $4 \mathrm{hr}$ of the dark cycle (Fig. 2, bottom panel). ANOVA and post hoc tests showed decreases in food intake of 29.7, 33.4, and $67.8 \%$ after 3, 5, and 10 nmol doses of Ro27-3225, respectively $(p<0.05)$. In addition, $10 \mathrm{nmol}$ of Ro27-3225 reliably suppressed food intake relative to both 3 and $5 \mathrm{nmol}$ of Ro27-3225 ( $p<0.05$ ). (Both the agonist and the antagonist 

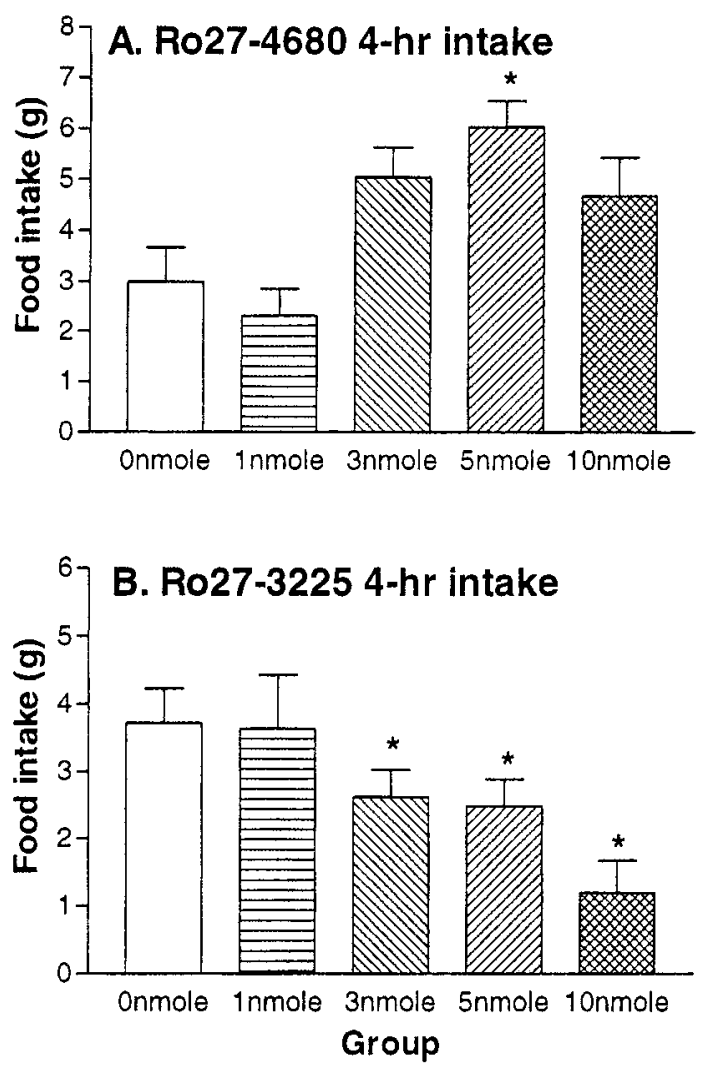

Figure 2. Rat food intake. Mean + SEM 4 hr food intake (grams) after i3vt administration of the selective MC4R antagonist Ro27-4680 $(A)$ and the agonist Ro27-3225 (B). ${ }^{*} p<0.05$.

elicited barrel rolling in some of the rats at doses of $10 \mathrm{nmol}$ or higher. These doses were not included in subsequent experiments.) Additionally, cumulative food intake after $24 \mathrm{hr}$ was not different between groups.

\section{Experiment 3: food intake in $d b / d b$ mice}

To investigate the hypothesis that CNS melanocortin signaling is downstream of the actions of leptin to reduce food intake and body weight, we administered Ro27-3225 to $d b / d b$ mice that lack functional long-form leptin receptors. As depicted in Figure 3, Ro27-3225 reliably reduced food intake relative to intraperitoneal saline equivalently in both wild-type and $d b / d b$ mice $(50.5$ and $38.5 \%$, respectively) over a $4 \mathrm{hr}$ period when administered at the beginning of the dark cycle (both $p<0.05$ ). As in experiment 2 , there were no differences in $24 \mathrm{hr}$ cumulative food intake between Ro27-3225 and saline injections.

\section{Experiment 4: CTA}

Figure $4 A$ depicts latency to reject intraorally infused saccharine during the test for CTA. As depicted in that figure, when $\mathrm{LiCl}$ is paired with consumption of a saccharin solution, rats rapidly (61 sec) reject the saccharin solution upon its next presentation. However, rats for which consumption of the saccharin solution was paired with the MC4R agonist consumed the saccharin solution for $5 \mathrm{~min}$ on its next presentation, indicating they had not associated the flavor with an aversive consequence of the drug. ANOVA and post hoc tests support the statistical validity of these conclusions. Rats that received saccharin paired with $\mathrm{LiCl}$ showed shorter rejection latencies than all other groups $(p<$ $0.01)$.
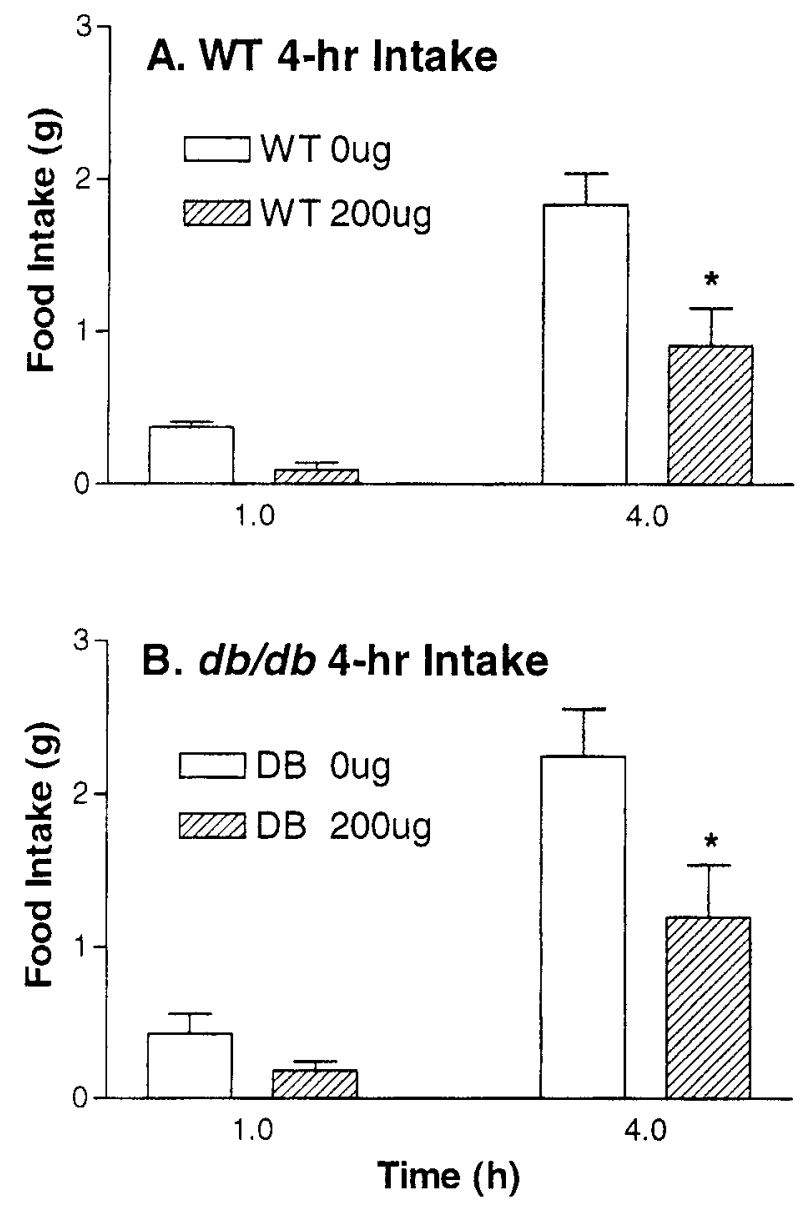

Figure 3. Mouse food intake. Mean + SEM food intake (grams) after intraperitoneal administration of $200 \mu \mathrm{g}$ of Ro27-3225 or saline in wildtype and obese $d b / d b$ mice. ${ }^{*} p<0.05$.

\section{Experiment 5: $\mathrm{NaCl}$ intake}

Rats avidly ingest $\mathrm{NaCl}$ solutions after they have been made $\mathrm{Na}^{+}$-deficient. This sodium appetite is sensitive to the effects of emetic agents such as $\mathrm{LiCl}$ (Stricker and Verbalis, 1990). Figure $4 B$ documents that $\mathrm{LiCl}$ significantly suppressed intake of a hypertonic $\mathrm{NaCl}$ solution in $\mathrm{Na}^{+}$-deficient rats. $\mathrm{LiCl}$ reduced $\mathrm{NaCl}$ intake by $56.3 \%$ compared with saline. Conversely, at doses that reliably suppress caloric intake, the MC4R agonist caused no reduction of $\mathrm{NaCl}$ intake in these rats. ANOVA and post hoc tests support the statistical validity of these conclusions. Rats that received injection of $\mathrm{LiCl}$ showed reduced $\mathrm{NaCl}$ intake relative to all other groups $(p<0.01)$. No statistical differences were found between rats that received Ro27-3225-saline and rats that received $\mathrm{CSF}$-saline. Therefore, whereas the aversive agent $\mathrm{LiCl}$ decreases multiple types of ingestion, the MC4R agonist has a selective effect to reduce food intake while not disturbing $\mathrm{NaCl}$ intake.

\section{Experiment 6: kaolin intake}

Under conditions associated with nausea and vomiting in other species, rats have an increased propensity to ingest clay (geophagia) (Mitchell et al., 1976). This active behavior on the part of the rat can be measured using a mixture of kaolin and acacia gum that can be hardened into clay pellets. Under normal circumstances (including food deprivation), rats will not consume the kaolin. Figure $4 C$ shows data from the 2 hr kaolin intake test. As 

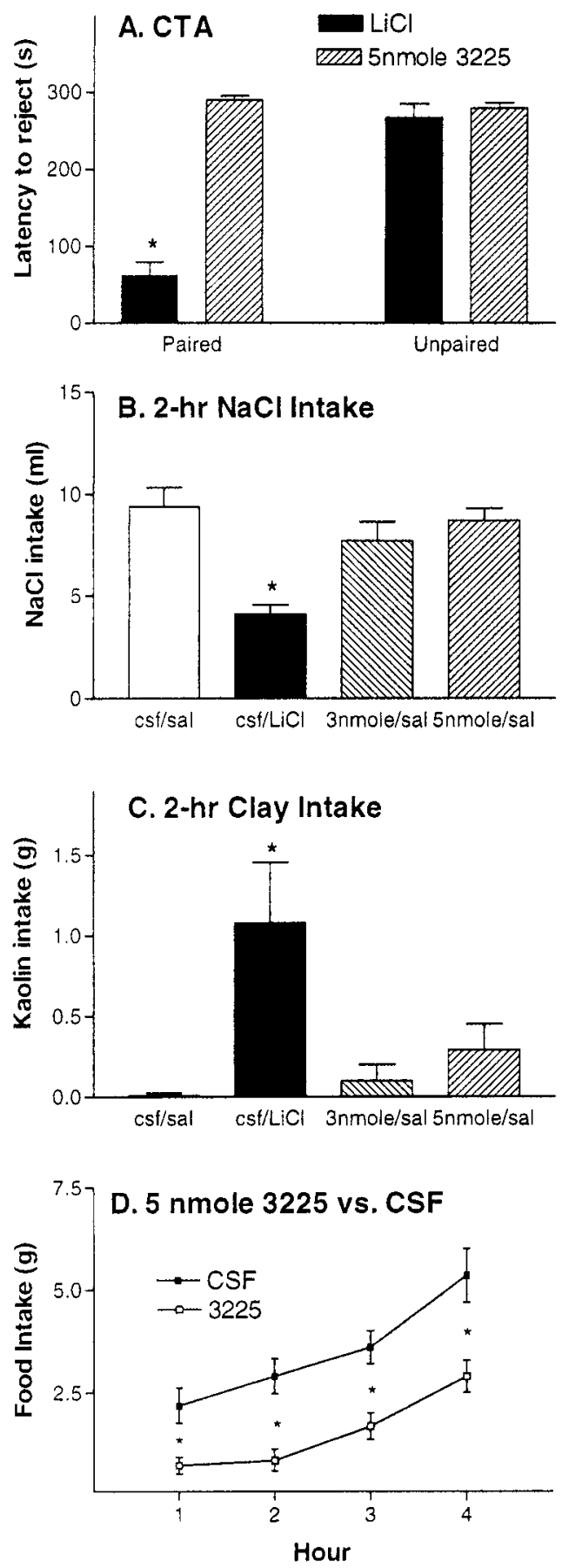

Figure 4. Aversive tests. A, Mean + SEM latency (seconds) to reject saccharine during $5 \mathrm{~min}$ test for conditioned taste aversion. $B$, Mean + SEM intake (milliliters) of $0.5 \mathrm{~mol}$ of $\mathrm{NaCl}$ after infusion-injection of CSF-saline, $3 \mathrm{nmol}$ of Ro27-3225-saline, CSF-LiCl, or $5 \mathrm{nmol}$ of Ro273225-saline. $C$, Mean + SEM kaolin clay intake (grams) after infusioninjection of CSF-saline, $3 \mathrm{nmol}$ of Ro27-3225-saline, CSF-LiCl, or 5 nmol of Ro27-3225-saline. $D$, Experiment 5. Within-subject food intake test $(n=8)$. Mean \pm SEM (grams) of chow consumed after i3vt infusion of either $2 \mu \mathrm{l}$ of $5 \mathrm{nmol}$ of Ro27-3225 or $2 \mu \mathrm{l}$ of CSF. ${ }^{*} p<0.05$.

depicted in that figure, $\mathrm{LiCl}$ but not Ro27-3225 administration significantly increased the consumption of kaolin by $108 \%$ relative to saline. ANOVA and post hoc tests confirm the statistical validity of this assessment. Rats that received $\mathrm{LiCl}$ consumed reliably less kaolin than rats receiving saline or $3225(p<0.05)$.

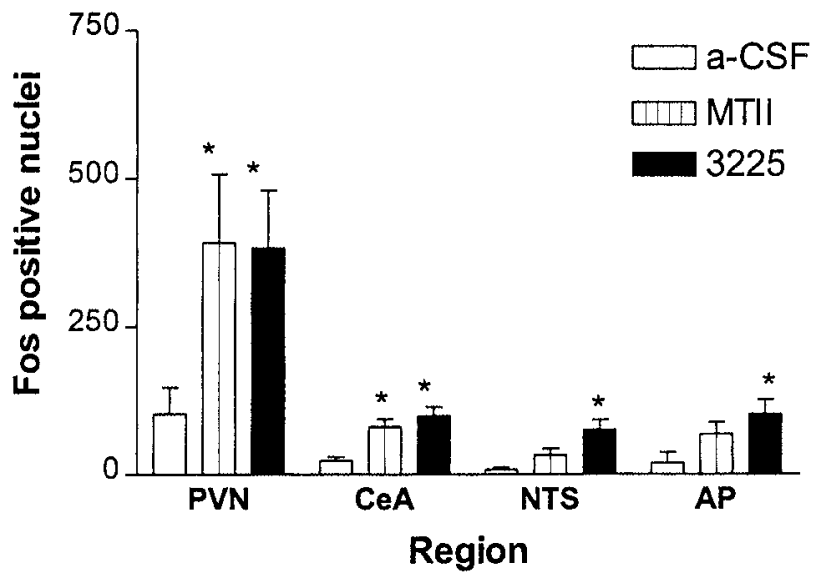

Figure 5. c-Fos immunoreactivity. Mean + SEM c-Fos-positive neurons in the PVN, CeA, AP, and NTS. * $p<0.05$.

\section{Experiment 7: $5 \mathrm{nmol}$ of Ro27-3225 food intake}

Figure $4 D$ shows the time course of the changes of food intake in grams of rats receiving either $5 \mathrm{nmol}$ Ro27-3225 or a-CSF. As in previous experiments, relative to saline, $5 \mathrm{nmol}$ of Ro27-3225 reliably suppressed food intake at $1,2,3$, and $4 \mathrm{hr}$ intake by 66.7, $70.3,53.1$, and $45.9 \%$, respectively $(p<0.05)$. As in experiment 2 , the effectiveness of the MC4R agonist was relatively short-lived. There was no reduction of cumulative food intake after $24 \mathrm{hr}$.

\section{Experiment 8: c-Fos expression}

Both Ro27-3225 and MTII increased c-FLI in the PVN (384 and $376 \%$, respectively) and CeA (352 and 431\%, respectively), although only Ro27-3225 produced reliable increases in hindbrain structures. However, patterns of c-FLI were not different between MTII and Ro-273225. Figure 5 shows c-FLI in PVN, CeA, NTS, and AP after a-CSF, $5 \mathrm{nmol}$ of Ro27-3225, and $1 \mathrm{nmol}$ of MTII. In all areas, $5 \mathrm{nmol}$ of Ro27- 3225 led to a reliable increase c-FLI relative to a-CSF. After 1 nmol of MTII, on the other hand, c-FLI was significantly increased in PVN (384\%) and CeA (352\%). The c-FLI increases in NTS $(425 \%)$ and AP $(347 \%)$ were marginally significant $(p<0.1)$ after administration of MTII. Figure 6 shows photomicrographs of representative brain sections after c-Fos immunocytochemistry. $A, B$, and $C$ show sections from representative subjects receiving a-CSF, $1 \mathrm{nmol}$ of MTII, and $5 \mathrm{nmol}$ of Ro-273225, respectively.

\section{DISCUSSION}

The selective MC4R agonist Ro27-3225 reduced 4 hr food intake dose-dependently in both rats and obese $d b / d b$ mice. Furthermore, the selective MC4R antagonist Ro27-4680 dose-dependently increased food intake in rats. These findings suggest that effects on the MC4R are sufficient to explain the feeding responses induced by the nonselective MC ligands (e.g., MTII and SHU-9119). Suppression of food intake can occur for many reasons, including stress, motor impairment, and visceral illness (malaise). To investigate whether these novel MC4R ligands reduced food intake through other, nonspecific mechanisms, including gastric distress or illness, we used a series of behavioral measures that are sensitive to aversive consequences. The prototypical aversive agent used in such studies is LiCl. When toxic doses are administered to emetic species (such as dogs and primates), $\mathrm{LiCl}$ reduces food intake and elicits vomiting, whereas humans verbally report feelings of visceral illness. In rats, a nonemetic species, 

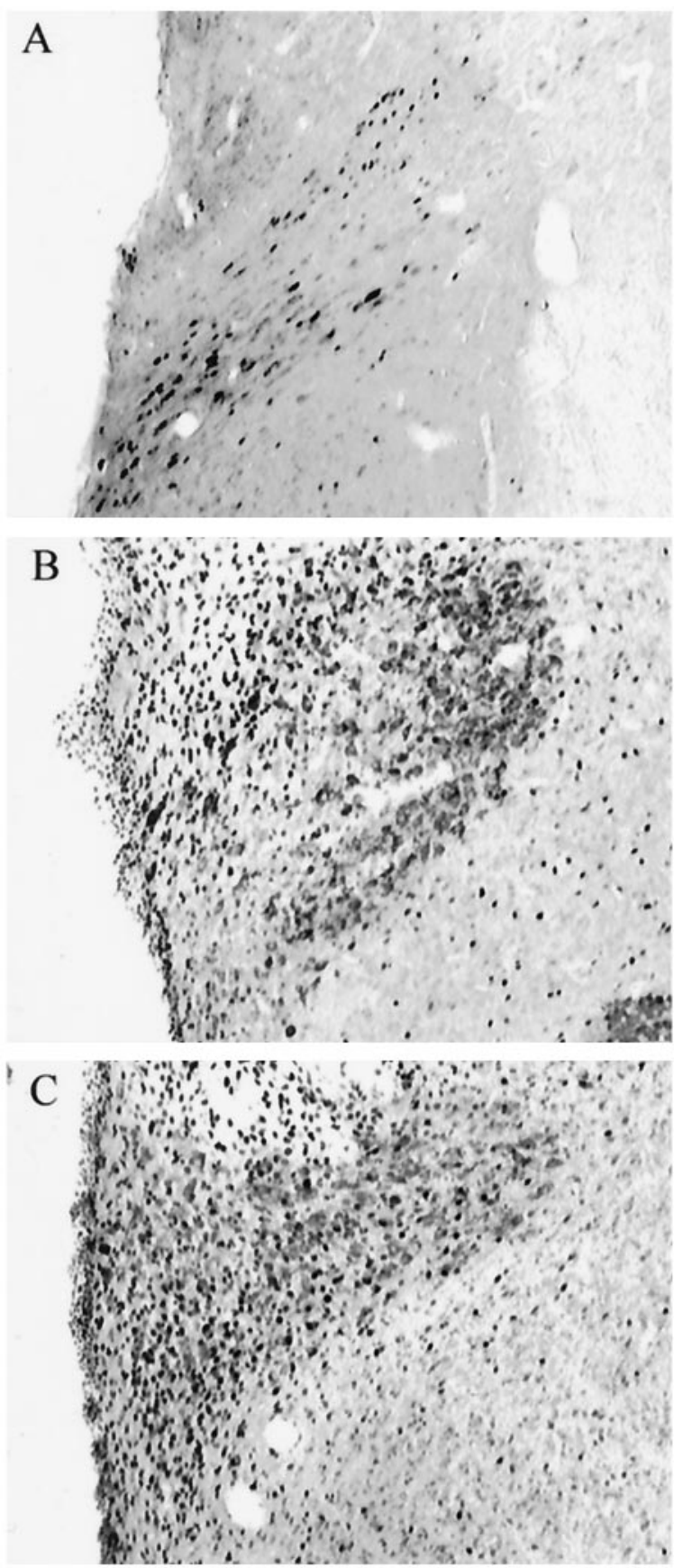

Figure 6. c-Fos immunoreactivity. Photomicrographs showing representative coronal PVN sections from control $(A), \operatorname{Ro} 27-3225(B)$, and MTII (C) rats.

$\mathrm{LiCl}$ reduces food intake and it also alters other behaviors that can be effectively measured.

The most commonly applied measure for the aversive effects of $\mathrm{LiCl}$ and other treatments is CTA learning. In this paradigm, rats are presented with a novel, preferred flavor such as saccharin, followed by administration of an aversive stimulus (e.g., $\mathrm{LiCl}$ ). Subsequently, rats are presented the same flavor in the absence of the aversive stimulus, and the extent to which the flavor is rejected provides a quantitative measure of its aversive consequences. Recent work has demonstrated that ventricular administration of some anorectic peptides [e.g., glucagon-like peptide
(GLP) 1 (7-36) amide or GLP-1] cause robust CTAs, whereas administration of others (e.g., leptin) does not (Thiele et al., 1997).

In the second series of experiments, the MC4R agonist was compared with $\mathrm{LiCl}$ on behavioral measures designed to assess the presence of aversive qualities. Three separate experiments collectively indicated that, although the MC4R agonist potently suppresses food intake, it does so without any evidence of aversive effects measured by either CTA formation or by geophagia, whereas these effects were readily demonstrated after the administration of $\mathrm{LiCl}$. These negative results are important because we found previously that the nonselective MC3/4R agonist MTII causes the formation of conditioned taste aversion (Thiele et al., 1998). The present results are therefore consistent with the hypothesis that MTII produces CTAs via its actions at MC3R rather than at MC4R.

Interestingly, the increase in c-FLI in several feeding relevant areas of the CNS caused by Ro27-3225 was compared with a dose of MTII that produced similar reductions of food intake at $2 \mathrm{hr}$. At these doses, Ro27-3225 and MTII produced similar numbers of c-FLI-positive cells in the PVN, CeA, NTS, and AP. Whereas the actions of the NTS and AP were nonsignificantly larger in the MTII-treated rats, the pattern of c-Fos induction is strikingly similar between the two treatments. Such data are consistent with the hypothesis that the effects of MTII to increase c-FLI in these areas is mediated primarily by the MC4 receptor. These data are interesting given the fact that MTII, but not Ro27-3225, supports the development of conditioned taste aversions. The aversive consequences associated with nonselective MC ligands may therefore be mediated through MC3R, whereas food intake effects mediated via MC4R. Furthermore, the similarities of c-FLI after infusion of MTII and Ro27-3225 suggest that the present c-Fos expression after MTII is primarily attributable to activation of the MC4 receptor and is not involved in aversive responses induced by MTII. Finally, the present data suggest that, unlike our previous suggestions (Thiele et al., 1997), c-Fos activation may not provide a reliable indication of aversive consequences.

Finally, it should be noted that $c$-fos expression results from neuronal activation. Thus, interpretations based on elevated levels of c-FLI are limited to effects in activate, rather than inhibit, neuronal responses.

The present data also are consistent with other findings, indicating relative importance of MC4R over MC3R in the control of food intake and body weight. First, selective genetic disruption of MC4R results in increased food intake and body weight (Huszar et al., 1997), and the mice are insensitive to the effects of MTII to reduce food intake (Marsh et al., 1999). The ability of MTII to reduce food intake, therefore, requires MC4R. Similarly, coadministration of MTII with a relatively selective MC4R antagonist (HS014) results in greatly decreased effectiveness of MTII to reduce food intake (Kask et al., 1998).

Although some controversy remains (Boston et al., 1997; Marsh et al., 1999), several lines of evidence indicate that the melanocortin system is an important target for the actions of leptin in the CNS in the regulation of food intake and body weight (Halaas et al., 1997; Seeley et al., 1997; Thornton et al., 1997; Mizuno et al., 1998; Satoh et al., 1998; Wilson et al., 1999) and that the central melanocortins are part of an endogenous system used to reduce food intake and body weight after periods of sustained positive energy balance (Hagan et al., 1999). The present results are the first to describe the effects of a selective MC4R agonist. This agonist, Ro27-3225, suppresses food intake in both rats and mice 
with no indication that the reduction is secondary to nonspecific or aversive consequences of the compound.

\section{REFERENCES}

Adan R, Cone R, Burbach J, Gispen W (1994) Differential effects of melanocortin peptides on neural melanocortin receptors. Mol Pharmacol 46:1182-1190.

Boston B, Blaydon K, Varnerin J, Cone R (1997) Independent and additive effects of central POMC and leptin pathways on murine obesity. Science 278:1641-1644.

Cheung CC, Clifton DK, Steiner RA (1997) Proopiomelanocortin neurons are direct targets for leptin in the hypothalamus. Endocrinology 138:4489-4492.

Fan W, Boston BA, Kesterson RA, Hruby VJ, Cone RD (1997) Role of melanocortinergic neurons in feeding and the agouti obesity syndrome. Nature 385:165-168.

Fong TM, Mao C, MacNeil T, Kalyani R, Smith T, Weinberg D, Tota MR, Van der Ploeg LH (1997) ART (protein product of agoutirelated transcript) as an antagonist of MC-3 and MC-4 receptors. Biochem Biophys Res Commun 237:629-631.

Grill HJ, Ginsberg AB, Seeley RJ, Kaplan JM (1998) Brainstem application of melanocortin receptor ligands produces long-lasting effects on feeding and body weight. J Neurosci 18:10128-10135.

Hagan MM, Rushing PA, Schwartz MW, Yagaloff KA, Burn P, Woods SC, Seeley RJ (1999) Role of the CNS melanocortin system in the response to overfeeding. J Neurosci 19:2362-2367.

Halaas JL, Boozer C, Blair-West J, Fidahusein N, Denton DA, Friedman JM (1997) Physiological response to long-term peripheral and central leptin infusion in lean and obese mice. Proc Natl Acad Sci USA 94:8878-8883.

Huszar D, Lynch CA, Fairchild-Huntress V, Dunmore JH, Fang Q, Berkemeier LR, Gu W, Boston BA, Cone RD, Smith FJ, Campfield LA, Burn P, Lee F (1997) Targeted disruption of the melanocortin-4 receptor results in obesity in mice. Cell 88:131-141.

Kask A, Rago L, Wikberg J, Schioth H (1998) Evidence for involvement of the melanocortin MC4 receptor in the effects of leptin on food intake and body weight. Eur J Pharmacol 360:15-19.

Lu D, Willard D, Patel I, Kadwell S, Overton L, Kost T, Luther M, Chen W, Woychik R, Wilkison W, Cone R (1994) Agouti protein is an antagonist of the melanocyte-stimulating-hormone receptor. Nature 371:

799-802.

Marsh DJ, Hollopeter G, Huszar D, Laufer R, Yagaloff KA, Fisher SL, Burn P, Palmiter RD (1999) Response of melanocortin-4 receptordeficient mice to anorectic and orexigenic peptides. Nat Genet 21:119-122.

Mitchell D, Wells C, Hoch N, Lind K, Woods SC, Mitchell LK (1976) Poison induced pica in rats. Physiol Behav 17:691-697.

Mizuno TM, Kleopoulos SP, Bergen HT, Roberts JL, Priest CA, Mobbs CV (1998) Hypothalamic pro-opiomelanocortin mRNA is reduced by fasting and [corrected] in ob/ob and $\mathrm{db} / \mathrm{db}$ mice, but is stimulated by leptin. Diabetes 47:294-297.

Mountjoy KG, Wong J (1997) Obesity, diabetes and functions for proopiomelanocortin-derived peptides. Mol Cell Endocrinol 128: 171-177.

Mountjoy KG, Mortrud MT, Low MJ, Simerly RB, Cone RD (1994)
Localization of the melanocortin-4 receptor (MC4-R) in neuroendocrine and autonomic control circuits in the brain. Mol Endocrinol 8:1298-1308.

Ollmann MM, Wilson BD, Yang YK, Kerns JA, Chen Y, Gantz I, Barsh GS (1997) Antagonism of central melanocortin receptors in vitro and in vivo by agouti-related protein. Science $278: 135-138$.

Ollmann MM, Lamoreux ML, Wilson BD, Barsh GS (1998) Interaction of Agouti protein with the melanocortin 1 receptor in vitro and in vivo. Genes Dev 12:316-330.

Rossi M, Kim M, Morgan D, Small C, Edwards C, Sunter D, Abusnana S, Goldstone A, Russell S, Stanley S, Smith D, Yagaloff K, Ghatei M, Bloom S (1998) A C-terminal fragment of Agouti-related protein increases feeding and antagonizes the effect of alpha-melanocyte stimulating hormone in vivo. Endocrinology 139:4428-4431.

Satoh N, Ogawa Y, Katsuura G, Numata Y, Masuzaki H, Yoshimasa Y, Nakao K (1998) Satiety effect and sympathetic activation of leptin are mediated by hypothalamic melanocortin system. Neurosci Lett 249:107-110.

Schioth HB, Muceniece R, Wikberg JE (1996) Characterisation of the melanocortin 4 receptor by radioligand binding. Pharmacol Toxicol 79:161-165.

Seeley RJ, Yagaloff KA, Fisher SL, Burn P, Thiele TE, van Dijk G, Baskin DG, Schwartz MW (1997) Melanocortin receptors in leptin effects. Nature 390:349.

Seeley RJ, van Dijk G, Campfield LA, Smith FJ, Nelligan JA, Bell SM, Baskin DG, Woods SC, Schwartz MW (1996) The effect of intraventricular administration of leptin on food intake and body weight in the rat. Horm Metab Res 28:664-668.

Stricker EM, Verbalis JG (1990) Sodium appetite. In: Handbook of behavioral neurobiology: neurobiology of food and fluid intake (Stricker EM, ed), pp 45-60. New York: Plenum.

Thiele TE, van Dijk G, Campfield LA, Smith FJ, Burn P, Woods SC, Bernstein IL, Seeley RJ (1997) Central administration of GLP-1, but not leptin, produce conditioned taste aversions in the rat. Am J Physiol 272:R726-R730.

Thiele TE, van Dijk G, Yagaloff KA, Fisher SL, Schwartz MW, Burn P, Seeley RJ (1998) Central infusion of melanocortin agonist MTII in rats: effects on eating, body weight, cFos expression and taste aversion. Am J Physiol 274:R248-R254.

Thornton JE, Cheung CC, Clifton DK, Steiner RA (1997) Regulation of hypothalamic proopiomelanocortin mRNA by leptin in ob/ob mice. Endocrinology 138:5063-5067.

Tsujii S, Bray GA (1989) Acetylation alters the feeding response to MSH and beta-endorphin. Brain Res Bull 23:165-169.

van Dijk G, Thiele TE, Donahey JCK, Campfield LA, Smith FJ, Burn P, Bernstein IL, Woods SC, Seeley RJ (1996) Central infusion of leptin and GLP-1 (7-36) amide differentially stimulate c-Fos-like immunoreactivity in the rat brain. Am J Physiol 271:R1096-R1100.

Wilson B, Bagnol D, Kaelin C, Ollmann M, Gantz I, Watson S, Barsh G (1999) Physiological and anatomical circuitry between Agouti-related protein and leptin signaling. Endocrinology 140:2387-2397.

Woods SC, Seeley RJ, Porte DJ, Schwartz MW (1998) Signals that regulate food intake and energy homeostasis. Science 280:1378-1383.

Xia Y, Wikberg J, Chhajlani V (1995) Expression of melanocortin 1 receptor in periaqueductal gray matter. NeuroReport 6:2193-2196. 